\title{
SISTEM INFORMASI PEMANTAUAN ABSENSI SISWA BERBASIS SMS (Short Message Service) Studi Kasus di MTsN Tambakberas Jombang
}

\author{
Siti Sufaidah \\ Prodi Sistem Informasi \\ STMIK Bahrul Ulum Tambakberas Jombang
}

\begin{abstract}
Abstrak
Tujuan Penelitian ialah untuk meningkatkan layanan informasi absensi kepada orang tua/wali siswa di Madrasah Tsanawiyah Negeri Tambakberas Jombang. Dengan metode analisis maka sistem yang sedang digunakan atau berjalan pada suatu lembaga dapat diketahui kekurangan serta kebutuhan dari lembaga tersebut. Hasil analisis tersebut dibuat ke dalam laporan yang nantinya akan digunakan sebagai panduan untuk merancang suatu sistem. hasil rancangan sistem tersebut dapat digunakan sebagai panduan untuk membuat suatu aplikasi.

Penelitian yang dilakukan di Madrasah Tsanawiyah Negeri Tambakberas Jombang didapatkan hasil bahwa lembaga pendidikan tersebut mempunyai kendala dalam menangani absensi siswa, karena untuk menangani masalah absensi diperlukan kerjasama antara pihak sekolah dan pihak orang tua atau pihak-pihak lain yang terkait. Sedangkan sarana yang digunakan untuk menghubungkan antara pihak sekolah dan orang tua sangat terbatas. Dengan adanya masalah tersebut didapatkan solusi yaitu dengan membuatkan sebuah sistem informasi pemantauan absensi siswa dalam bentuk aplikasi yang berbasis SMS (Short Message Service). Aplikasi absensi berbasis SMS secara otomatis akan mengirim pesan ke orang tua jika anak didiknya tidak masuk sekolah dengan biaya yang murah dan orang tua pun dapat melihat rekap absensi anaknya dengan mengirimkan SMS request. Dengan adanya aplikasi tersebut komunikasi antara pihak sekolah, orang tua dan pihak yang terkait diharapkan dapat berjalan baik. Kesimpulan dan saran dari hasil penelitian ini adalah dapat membantu menyelesaikan masalah yang ada di dalam lembaga pendidikan tersebut, dan juga diharapkan bahwa aplikasi ini dikembangkan agar menjadi lebih baik lagi dari sebelumnya.
\end{abstract}

Kata kunci $\quad$ : Absensi, SMS, Siswa, Orang Tua

\section{PENDAHULUAN}

Kemajuan teknologi informasi yang demikian pesat serta potensi pemanfaatannya secara luas membuka peluang bagi pengaksesan, pengelolaan dan pendayagunaan informasi dalam volume yang besar secara cepat dan akurat. Kemajuan tersebut salah satunya dapat diwujudkan dalam bidang pendidikan. Hal ini dikarenakan bidang pendidikan adalah faktor penting dalam mewujudkan kesejahteraan dan kemajuan suatu bangsa. Salah satu faktor yang menentukan berhasil tidaknya suatu pendidikan adalah kedisiplinan siswa. Di sekolah yang tertib akan selalu menciptakan proses pembelajaran yang baik. Sebaliknya, pada sekolah yang tidak tertib kondisinya akan jauh berbeda. Pelanggaran-pelanggaran yang terjadi sudah dianggap barang biasa dan untuk memperbaiki keadaan yang demikian tidaklah mudah. Hal ini diperlukan kerja keras dari berbagai pihak untuk mengubahnya, sehingga berbagai jenis pelanggaran terhadap disiplin dan tata tertib sekolah tersebut perlu dicegah dan ditangkal.

Kita dapat menciptakan komunikasi yang efektif antara anak orang tua dan sekolah dengan pemanfaatan teknologi informasi. Dengan teknologi SMS (Short Message Service) misalnya. Kita telah mengenal teknologi ini sejak beberapa tahun terakhir. Dengan biaya yang sangat murah, teknologi SMS dapat dijadikan ajang untuk saling bertukar informasi. Bahkan beberapa operator seluler memberikan discount khusus bahkan gratis terhadap pemakai teknologi SMS. Dengan sistem SMS, diharapkan akan mampu memberikan solusi yang terbaik dalam hal membangun komunikasi efektif antara pihak sekolah dan 
keluarga dalam pengawasan anak secara baik, tepat dan tentunya dengan biaya yang sangat murah.

Madrasah Tsanawiyah Negeri Tambakberas Jombang merupakan salah satu dari sekian banyak sekolah yang sistem absensinya masih dilakukan secara manual sehingga pihak orang tua dan sekolah tidak dapat memantau secara cepat jika ada siswa yang tidak masuk akibatnya langkah untuk mengambil tindakan pun terhambat. Sistem Informasi Pemantauan Absensi adalah salah satu aplikasi yang akan dibuat menggunakan bahasa pemrograman Visual Basic 6.0 dengan memanfaatkan kolaborasi antara teknologi barcode reader dan SMS melalui Handphone. Dengan sistem tersebut, setiap anak atau siswa dapat dipantau secara berkala oleh orang tuanya dalam hal kehadirannya di sekolah.

\section{ANALISIS SISTEM}

Sejak didirikan hingga menjadi MTsN, Lembaga ini sudah lima kali mengalami pergantian kepala madrasah, namun selalu terus mengalami kemajuan dan perkembangan. Masyarakat dan orang tua yang tergabung dalam BP 3 diwakili oleh pengurusnya selalu berperan aktif sebagaimana fungsinya memberikan kontribusi dalam memajukan madrasah.

Sistem yang sedang berjalan adalah sistem konvensional dimana guru BP pada awal bulan membagikan daftar hadir kepada semua ketua kelas. Proses pencatatan daftar hadir setiap hari dilakukan oleh pengurus kelas masing-masing dalam hal ini adalah sekretaris. Pada akhir bulan setiap ketua kelas mengumpulkan daftar hadir ke guru BP untuk dilakukan rekap bulanan. Dari hasil rekap daftar hadir inilah guru BP baru bisa mengetahui siapa saja siswa yang paling aktif dan yang paling banyak absensinya untuk selanjutnya mengambil tindakan.

\section{Permasalahan yang Sedang Terjadi}

Dengan sistem demikian, maka dapat menimbulkan kendala-kendala sebagai berikut

1. Proses penanganan siswa yang banyak absensinya menjadi lambat karena data rekap kehadirannya hanya bisa diketahui satu bulan sekali.

2. Kesulitan memberi informasi jika pada hari aktif ada orang tua / wali siswa yang menanyakan apakah anaknya hari itu masuk sekolah atau tidak, hal ini dikarenakan banyaknya kelas yang ada di sekolah ini.

3. Komunikasi kurang efektif antara orang tua / pengurus asrama dengan pihak sekolah mengenai kehadiran siswa karena tidak ada media yang menjembatani hal tersebut.

4. Daftar hadir kadang kurang valid karena prosesnya dilakukan oleh teman mereka sendiri.

\section{Usulan pemecahan Masalah}

Melihat masalah yang dihadapi tersebut, maka dibuatkanlah sebuah sistem berupa aplikasi penanganan absensi siswa berbasis Short Message Service (SMS) yang proses kehadirannya dilakukan dengan menggunakan peralatan komputer. Dengan sistem ini sebuah daftar hadir langsung bisa diketahui hasil rekapannya pada hari itu juga serta adanya pemberitahuan kepada orang tua atau pengurus asrama melalui Short Message Service (SMS) mengenai ketidak hadiran siswa pada hari tersebut. Sehingga diharapkan beberapa permasalahan yang timbul mengenai penanganan siswa yang absen dapat teratasi.

\section{RANCANGAN SISTEM}


A. Perancangan Database

1. Kamus data
a. Kamus data siswa
b. Kamus data kelas
c. Kamus data asrama
d. Kamus data Kehadiran
e. Kamus data Semester
f. Kamus data phonebook
g. Kamus data PhoneGroup
h. Kamus data Inbox
i. Kamus data respon
j. Kamus data outbox
k. Kamus data users

B. Data Flow Diagram (DFD)

1. Diagram Konteks Sistem Informasi Pemantauan Absensi Berbasis SMS

Diagram konteks di bawah ini menunjukkan secara garis besar bagaimana alur dari sistem informasi pemantauan absensi berbasis sms ini berjalan.

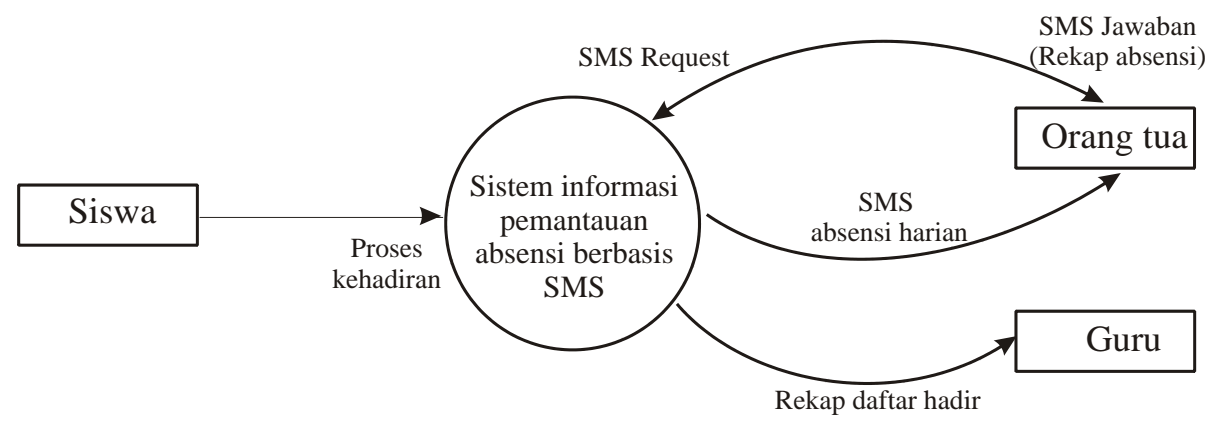

\section{Gambar 3.4 Diagram Konteks Sistem Informasi Pemantauan Absensi Berbasis SMS}

2. Data flow diagram 0 Level 1

Diagram 0 level 1 disini menjelaskan lebih detail dari diagram konteks di atas, dengan menggambarkan beberapa proses utama yang dilakukan dalam sistem ini.

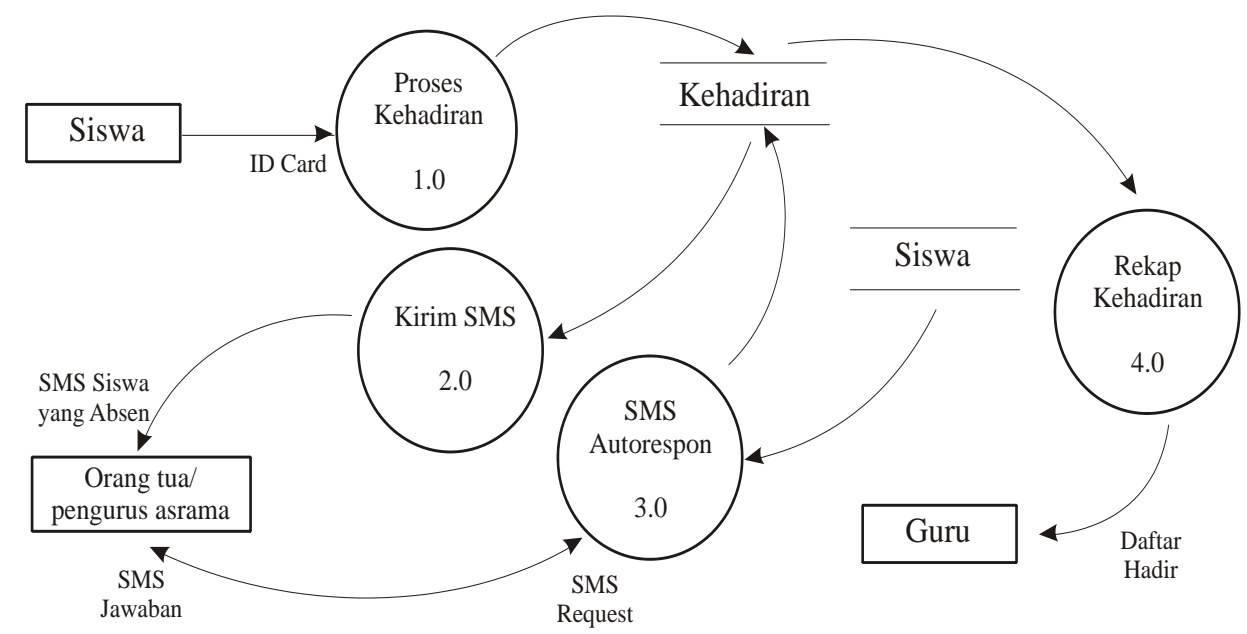

Gambar 3.5 Data flow diagram 0 Level 1

3. Data flow diagram 1.0 Level 2 
Diagram 1.0 level 2 ini menunjukkan rincian proses dari diagram level sebelumnya. Pada diagram ini dijelaskan bagaimana proses pencatatan kehadiran siswa dilakukan.

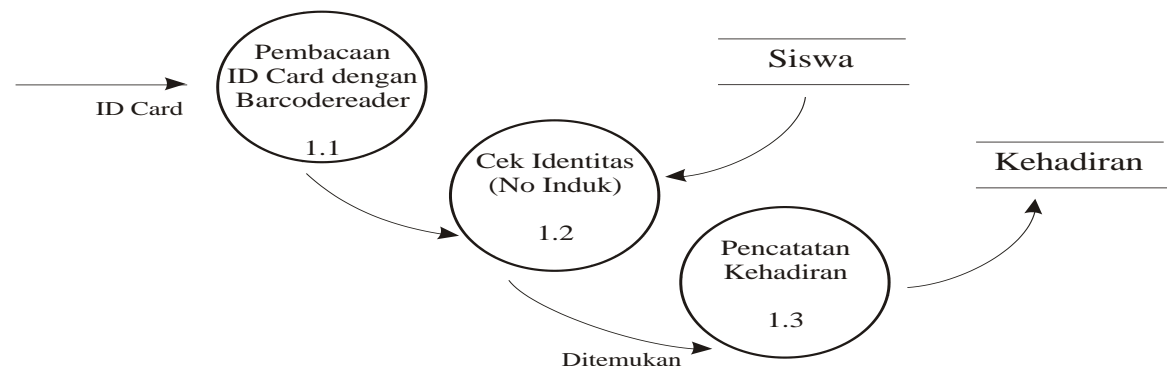

\section{Gambar 3.6 Data flow diagram 1.0 Level 2}

4. Data flow diagram 2.0 Level 2

Pada diagram ini dijelaskan bagaimana proses pengiriman informasi siswa yang absen melalui SMS kepada orang tua / pengurus.

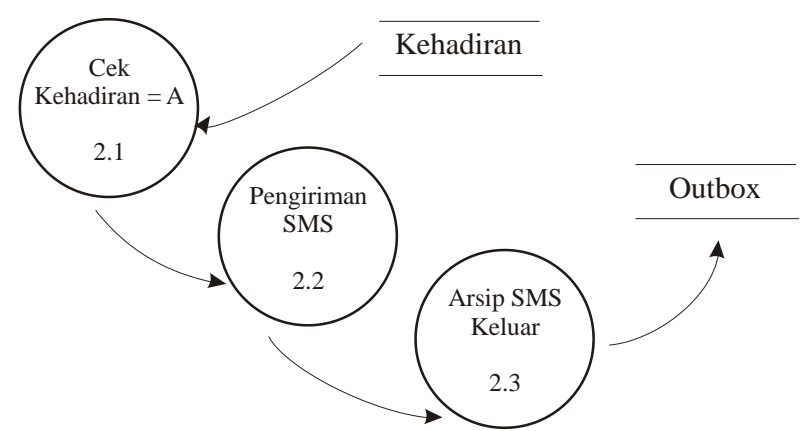

Gambar 3.7 Data flow diagram 2.0 Level 2

5. Data flow diagram 3.0 level 2

Diagram di bawah ini menjelaskan proses penanganan SMS Request dari Orang tua siswa atau dari nomor handphone yang teregister.

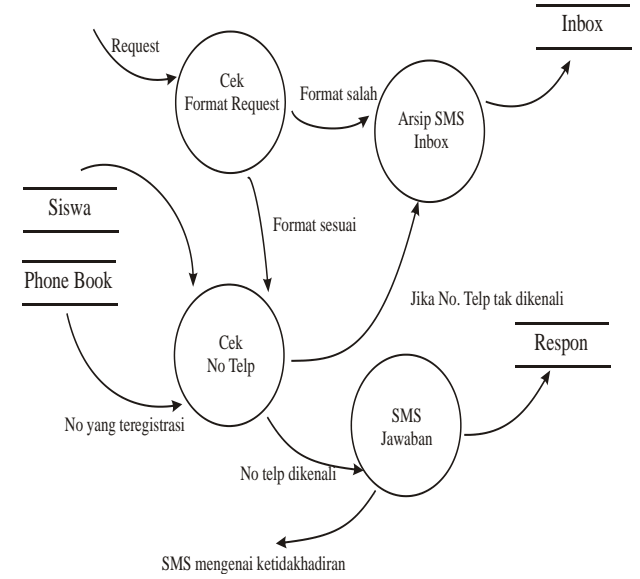


Gambar 3.8 Data flow diagram 2.0 Level 2

C. Desain Flowchart

1. Flowchart Input data Siswa

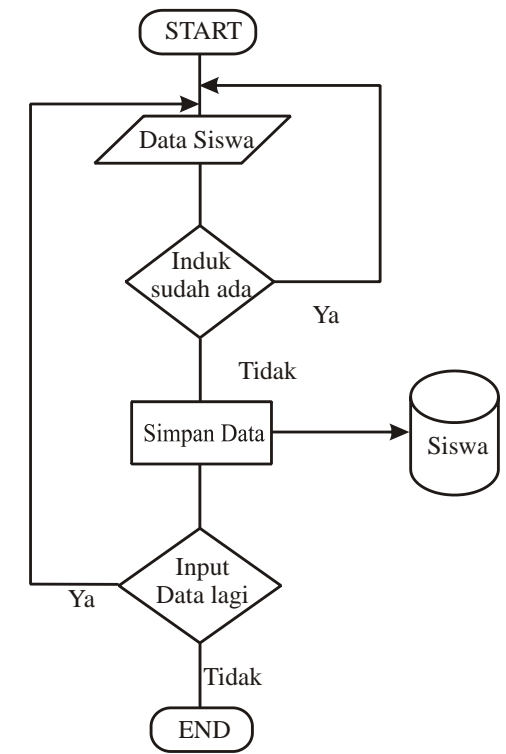

Gambar 3.9 Flowchart Input Data Siswa

2. Flowchart Proses Kehadiran Otomatis

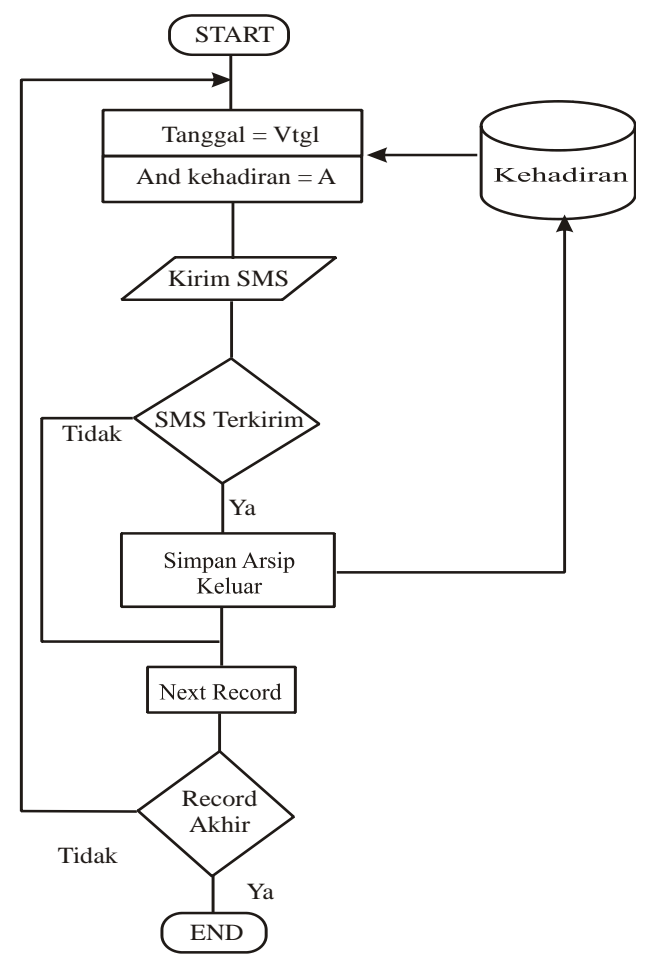




\section{Gambar 3.10 Flowchart Proses Kehadiran Otomatis}

3. Flowchart Pengiriman Data Absensi

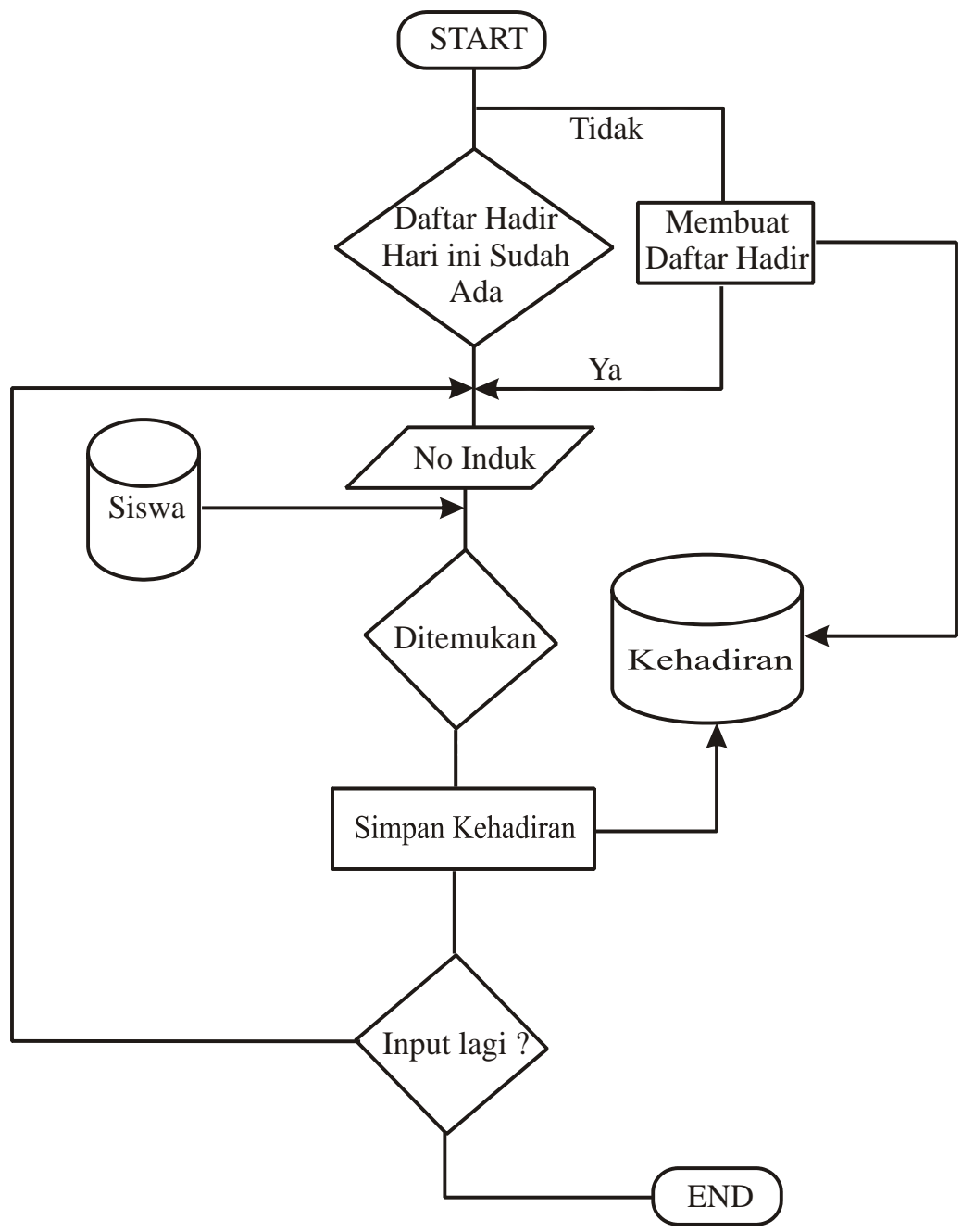

Gambar 3.11 Flowchart Pengiriman Data Absensi 
4. Flowchart SMS Autorespon

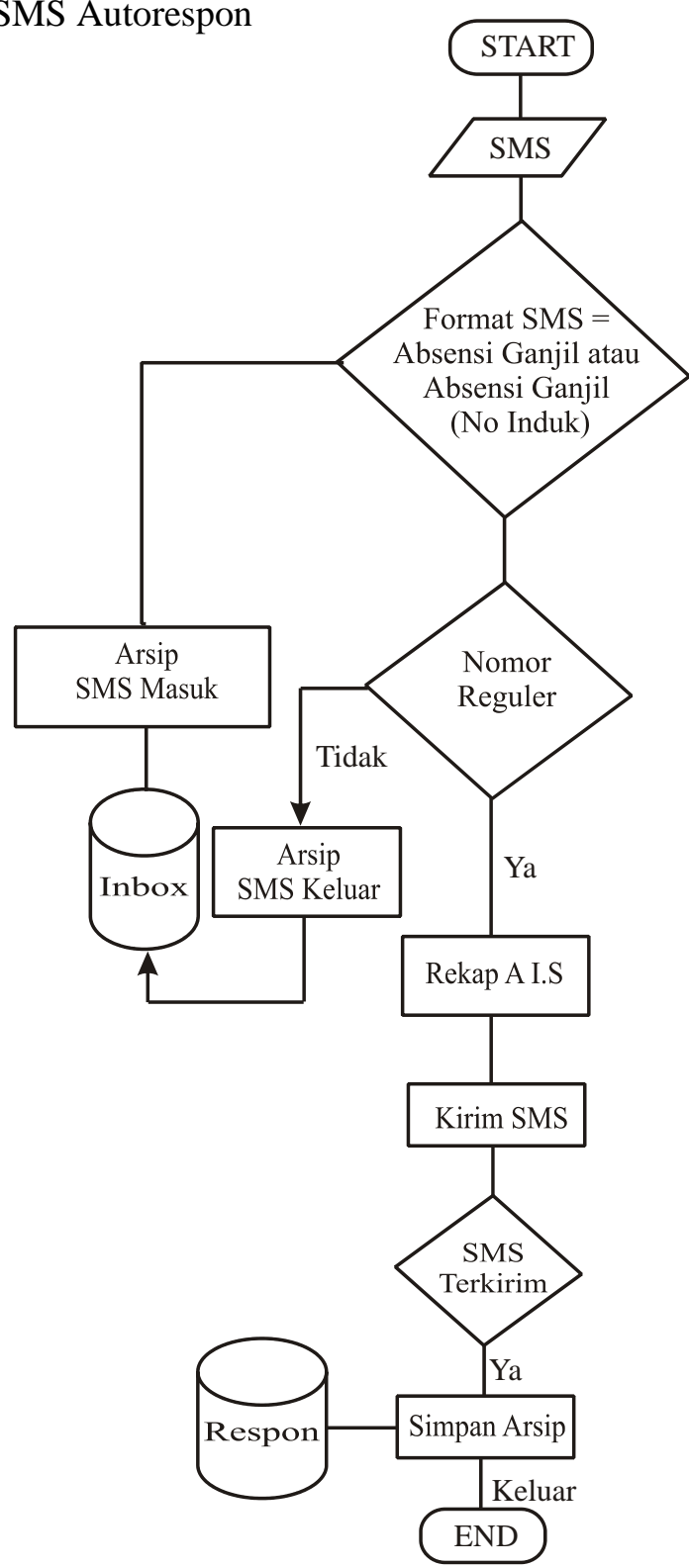

Gambar 3.12 Flowchart Pengiriman Data Absensi

D. Desain Form

1. Form Input Data Siswa

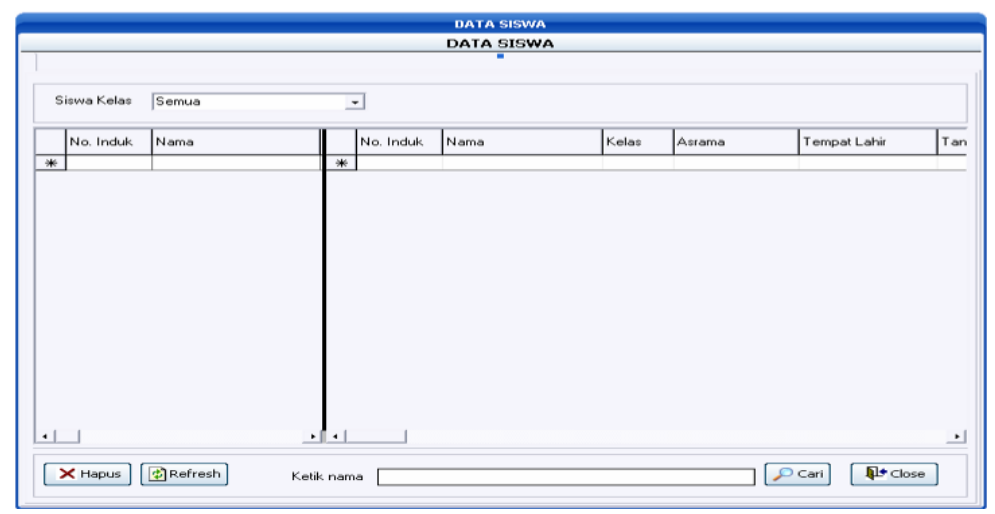

Gambar 3.13 Desain Form Input Data Siswa 


\begin{tabular}{|c|l|l|l|}
\hline No & \multicolumn{1}{|c|}{ Object } & \multicolumn{1}{|c|}{ Property } & \multicolumn{1}{c|}{ Value } \\
\hline \hline 1 & Form & Name & Frm_siswa \\
\hline 2 & Combobox & Name & Cbo_kelas \\
\hline 3 & TDBgrid & Name & Grid \\
\hline 4 & Command 1-4 & Name & $\begin{array}{l}\text { Cmd_hapus, cmd_refresh, } \\
\text { cmd_cari, cmd_close }\end{array}$ \\
\hline 5 & Textbox & Name & Txt_cari \\
\hline
\end{tabular}

2. Desain Form Kehadiran Otomatis

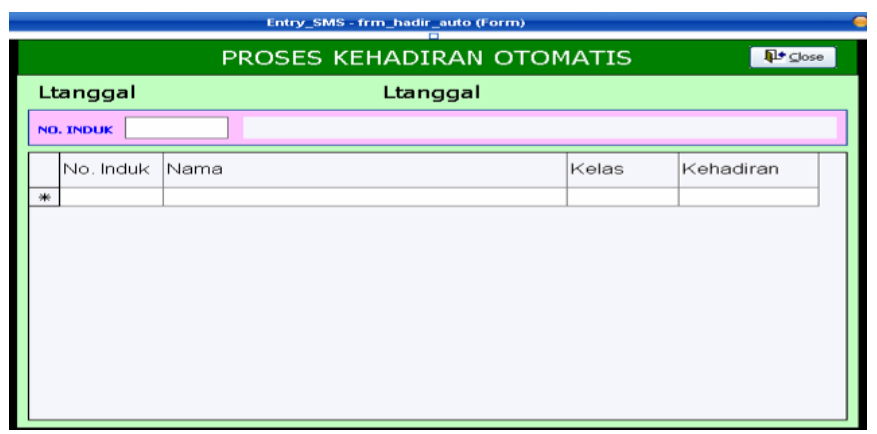

Gambar 3.14 Desain Form Kehadiran Otomatis

\begin{tabular}{|c|l|l|l|}
\hline No & \multicolumn{1}{|c|}{ Object } & Property & \multicolumn{1}{c|}{ Value } \\
\hline \hline 1 & Form & Name & Frm_hadir_auto \\
\hline 2 & Label $1,2,3$ & Name & Ljam, ltanggal, Lnama \\
\hline 3 & TDBgrid & Name & Grid \\
\hline 4 & Command 1 & Name & Cmd_close \\
\hline
\end{tabular}

3. Desain Form Hadir Manual

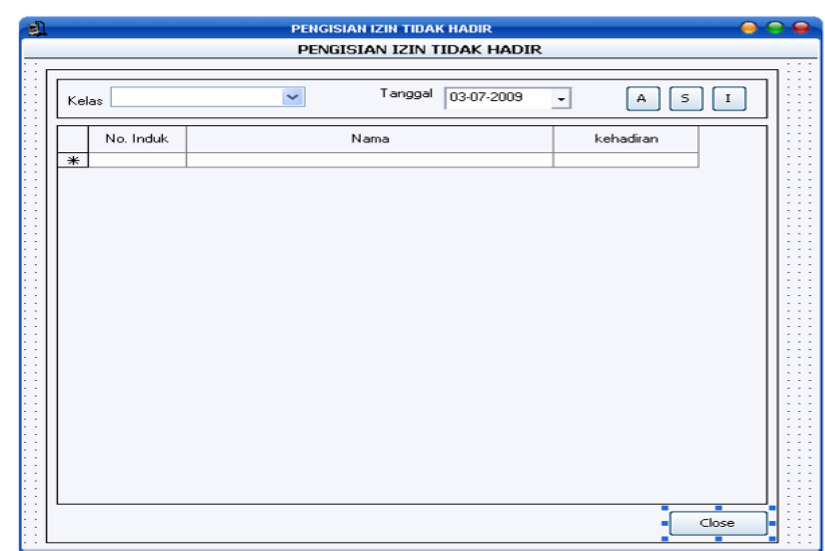

Gambar 3.15 Desain Form Hadir Manual 


\begin{tabular}{|c|l|l|l|}
\hline No & \multicolumn{1}{|c|}{ Object } & Property & \multicolumn{1}{c|}{ Value } \\
\hline \hline 1 & Form & Name & Frm_hadir_manual \\
\hline 2 & Combobox & Name & Cmd_kelas \\
\hline 3 & Datepicker & Name & Txt_tanggal \\
\hline 4 & TDBgrid & Name & Grid \\
\hline 5 & Command 1-4 & Name & Cmd_A, cmd_S, cmd_I, cmd_close \\
\hline & & Caption & A, S, I, Close \\
\hline
\end{tabular}

4. Desain Form SMS Manajer

a. Tab Setting

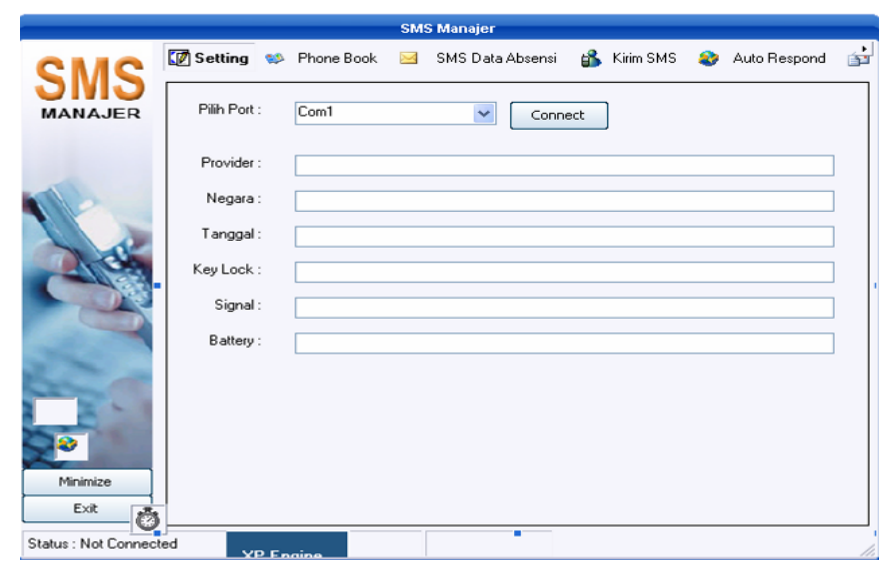

Gambar 3.16 Desain Form SMS Manajer (setting)

\begin{tabular}{|c|l|l|l|}
\hline No & \multicolumn{1}{|c|}{ Object } & \multicolumn{1}{c|}{ Property } & \multicolumn{1}{c|}{ Value } \\
\hline \hline 1 & Form & name & Frm_sms \\
\hline 2 & Combobox & Name & Cmd_port \\
\hline 3 & Textbox 1-6 & Name & $\begin{array}{l}\text { T1(0), T2(1), T3(2), T4(3), T5(4), } \\
\text { T6(5) }\end{array}$ \\
\hline 4 & Command1 & Name & Cmd_connect \\
\hline 5 & & Caption & connect \\
\hline
\end{tabular}

b. Tab SMS Data Absensi

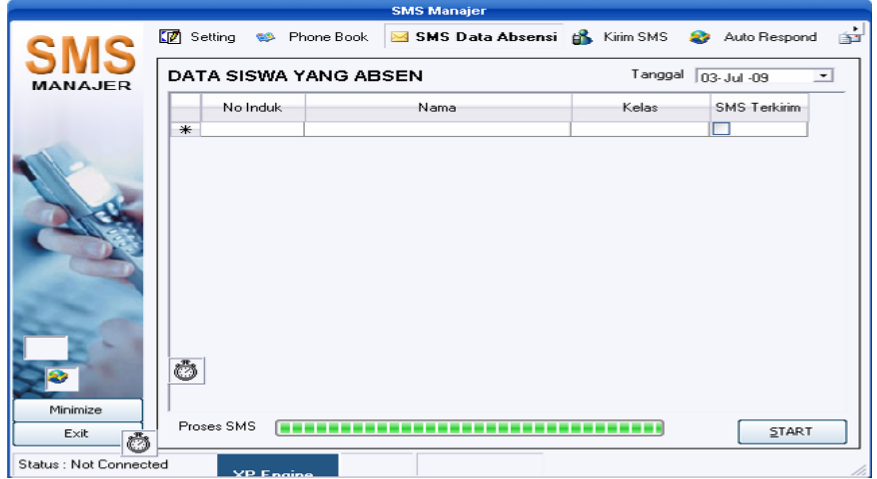

Gambar 3.17 Desain Form SMS Manajer (SMS Data Absensi) 


\begin{tabular}{|c|l|l|l|}
\hline No & \multicolumn{1}{|c|}{ Object } & Property & \multicolumn{1}{c|}{ Value } \\
\hline \hline 1 & Label & Caption & DATA SISWA YANG ABSEN \\
\hline 2 & Datepicker & Name & Date1 \\
\hline 3 & Tdbgrid & Name & Grid_sms \\
\hline 4 & Timer1 & Name & Timer_asbsensi \\
\hline & & Interval & 1000 \\
\hline 5 & Progressbar & Name & Bar1 \\
\hline 6 & Command1 & Name & Cmd_start \\
\hline
\end{tabular}

c. Tab Kirim SMS

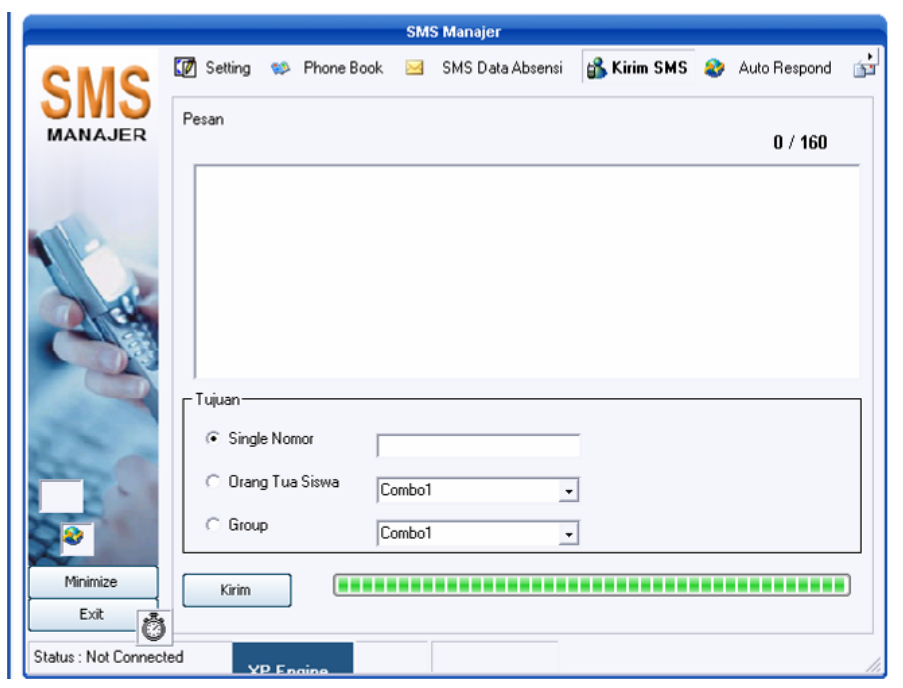

Gambar 3.18 Desain Form SMS Manajer (Kirim SMS)

\begin{tabular}{|c|l|l|l|}
\hline No & \multicolumn{1}{|c|}{ Object } & \multicolumn{1}{|c|}{ Property } & \multicolumn{1}{|c|}{ Value } \\
\hline \hline 1 & Option 1-3 & Name & Op(0), op(1), op(2) \\
\hline & & Caption & $\begin{array}{l}\text { Single nomor, orang tua siswa, } \\
\text { group }\end{array}$ \\
\hline 3 & Combobox 1-2 & Name & Cbo_kelas, cbo_group \\
\hline & Txtbox & Name & Txt_nomor \\
\hline & Command1 & Name & Cmd_kirim \\
\hline 4 & & Caption & Kirim \\
\hline 5 & Progressbar & Name & Bar2 \\
\hline
\end{tabular}

E. Desain Report

1. Desain report rekap daftar hadir perbulan

Report ini digunakan untuk mencetakan daftar hadir perbulan. 


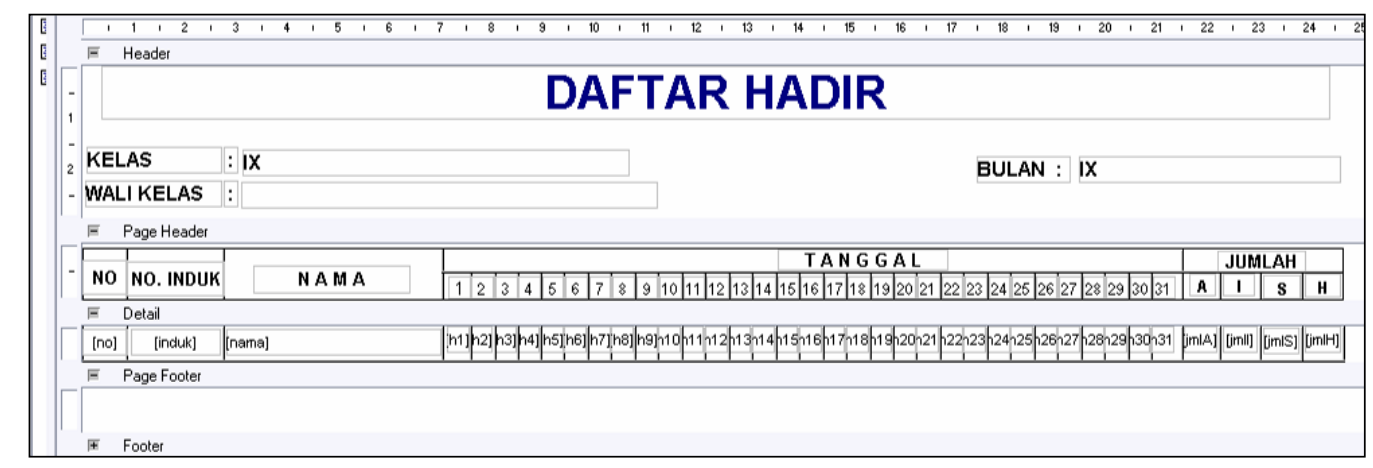

Gambar 3.19 Desain Report Rekap Daftar Hadir Perbulan

2. Desain report rekap daftar hadir persemester

Report ini digunakan untuk mencetak rekap kehadiran per semester (ganjil/genap).

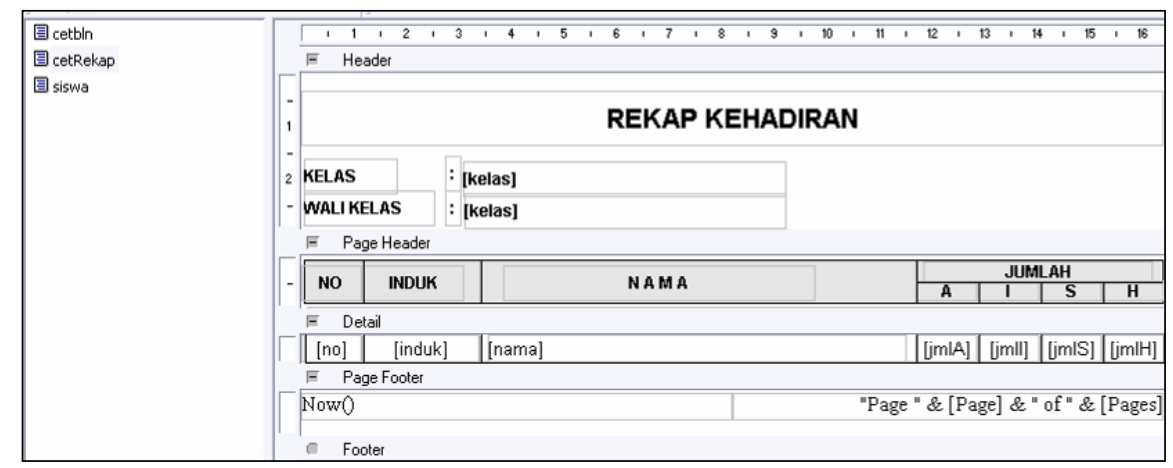

3. Desain report Kartu Tanda Siwa (KTS)

Report ini digunakan untuk mencetak kartu tanda siswa (KTS) yang di dalamnya terdapat barcode yang sesuai dengan nomor induk.

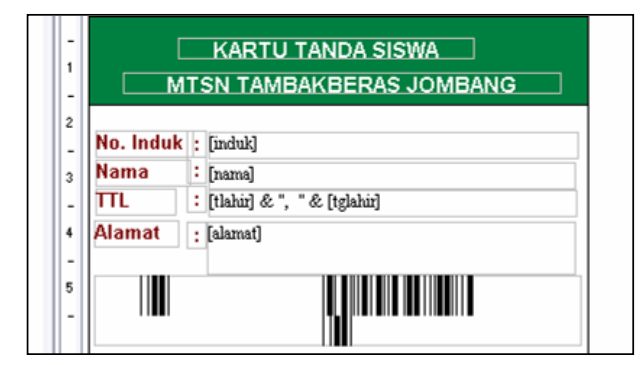

Gambar 3.21 Desain Report Kartu Tanda Siwa (KTS)

\section{IMPLEMENTASI DAN EVALUASI}

\subsection{Implementasi}

\subsubsection{Rencana Implementasi}

Di dalam mengimplementasikan sistem informasi pemantauan absensi berbasis short message service (SMS) dengan cara membuka aplikasi yang telah dibuat melalui shortcut atau langsung dibuka melalui windows explorer.

\subsubsection{Sarana yang Dibutuhkan dalam Implementasi}

1) Hardware

Spesifikasi komputer yang akan digunakan untuk menjalankan program ini direkomendasikan sebagai berikut:

(1) Processor $1.5 \mathrm{GHz}$

(2) RAM $512 \mathrm{MB}$

(3) HDD 40 GB 
(4) Monitor 15 “

(5) Keyboard

(6) Mouse

(7) Handphone GSM Nokia 3310 menggunakan kartu IM3 lengkap dengan kabel data

(8) Barcode Reader (duduk)

(9) VGA $64 \mathrm{MB}$

(10) Printer

2) Software

Software yang dibutuhkan untuk menjalankan server:

(1) Microsoft Windows XP

(2) Microsoft Data Akses Komponen

\subsubsection{Cara Pengoperasian Program}

1) Halaman Login

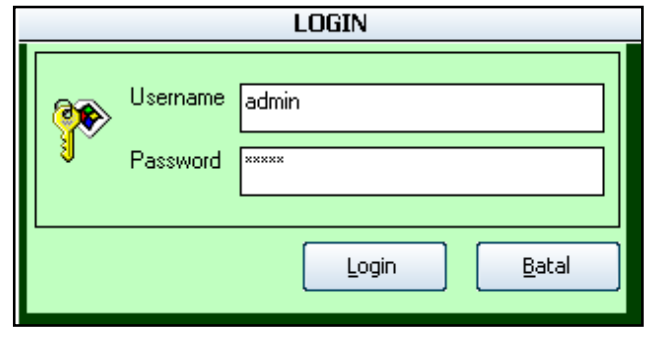

Gambar 4.1 Halaman Login

Pada halaman ini user diharuskan mengisi username dan password, lalu klik tombol login untuk masuk ke menu utama atau klik tombol batal untuk keluar dari aplikasi.

2) Halaman Menu Utama

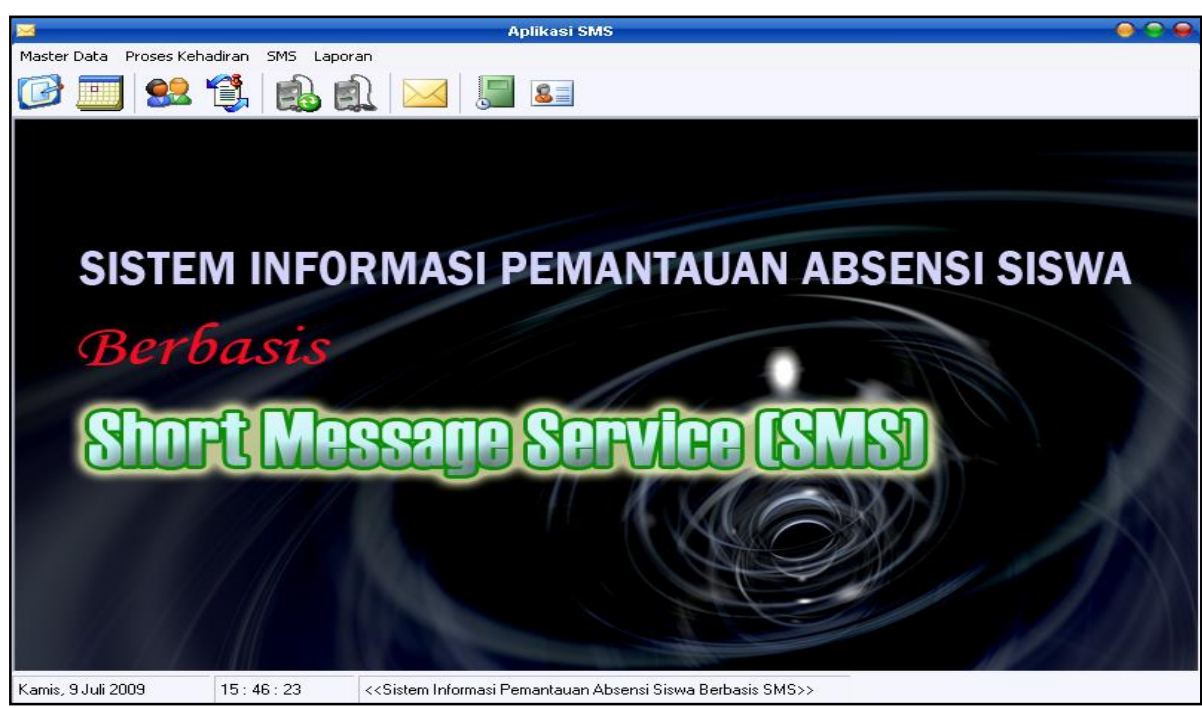

Pada halaman ini user dapat memilih menu apa yang akan dibuka. Menu Master Data berisi dengan sub menu data kelas / asrama, pengaturan semester, data siswa dan mutasi siswa. Menu Proses kehadiran berisi sub menu kehadiran otomatis dan kehadiran manual. Menu SMS berisi sub menu sms manajer. Menu Laporan berisi sub menu cetak daftar hadir, cetak KTS (Kartu Tanda Siswa). Selain menu user juga bisa menggunakan toolbar yang ada di bawah menu bar. 
3) Halaman Pengaturan Kelas / Asrama

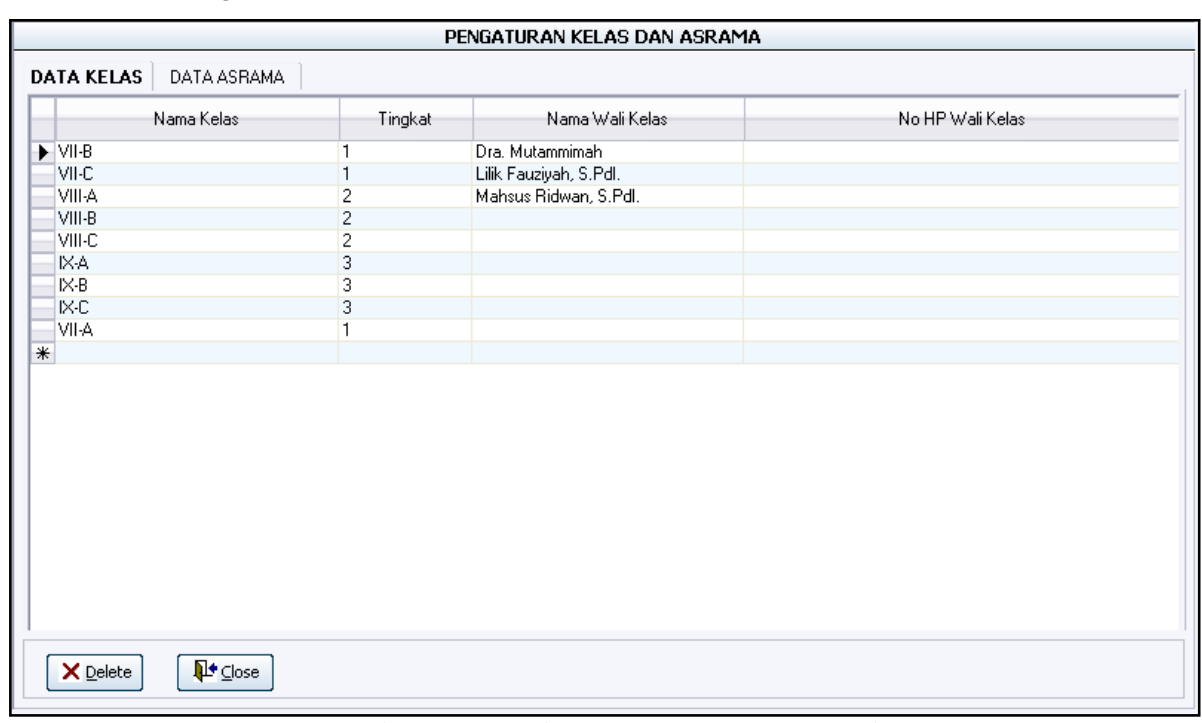

Gambar 4.3 Halaman Pengaturan Kelas / Asrama

Pada halaman ini user dapat memasukkan data kelas yang ada di sekolah tersebut dan data asrama pondok dengan cara langsung mengetik di tabel layaknya mengetik di microsoft excel.

Tombol delete untuk menghapus data dan tombol close untuk menutup halaman ini.

4) Halaman Pengaturan Semester

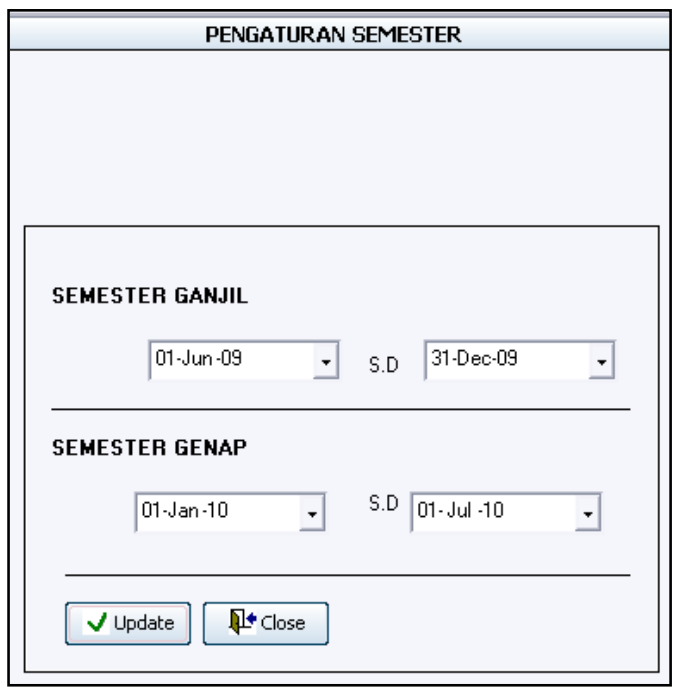

Gambar 4.4 Halaman Pengaturan Semester

Halaman ini digunakan untuk menentukan batas tanggal dimulai dan diakhirinya semester ganjil atau semester genap. Hal ini berfungsi ketika ada request sms permintaan absensi semester ganjil atau genap maka data yang diberikan sesuai dengan batas tanggal yang telah ditentukan tersebut. 
5) Halaman Input Data Siswa

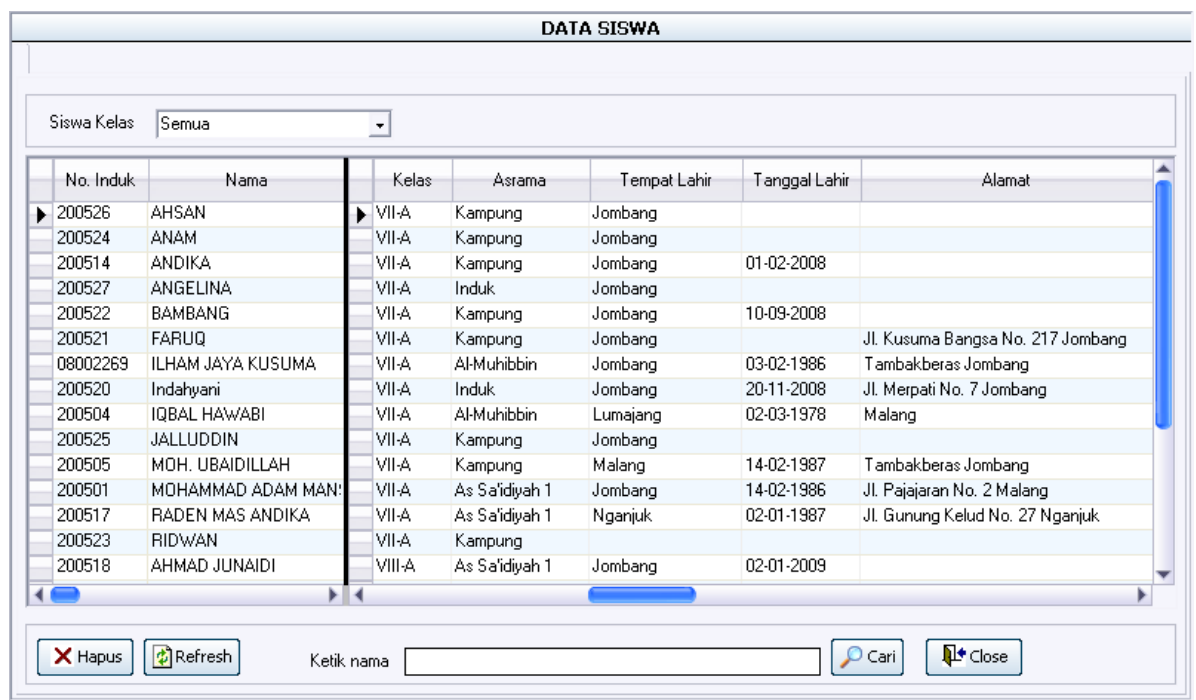

Halaman ini digunakan untuk menginputkan data siswa. Pilihan siswa kelas digunakan memfilter data sesuai kelas. Tombol hapus untuk mengahpus data, tombol refresh untuk merefresh data, tombol cari untuk mencari nama siswa dan tombol close untuk keluar.

6) Halaman mutasi siswa

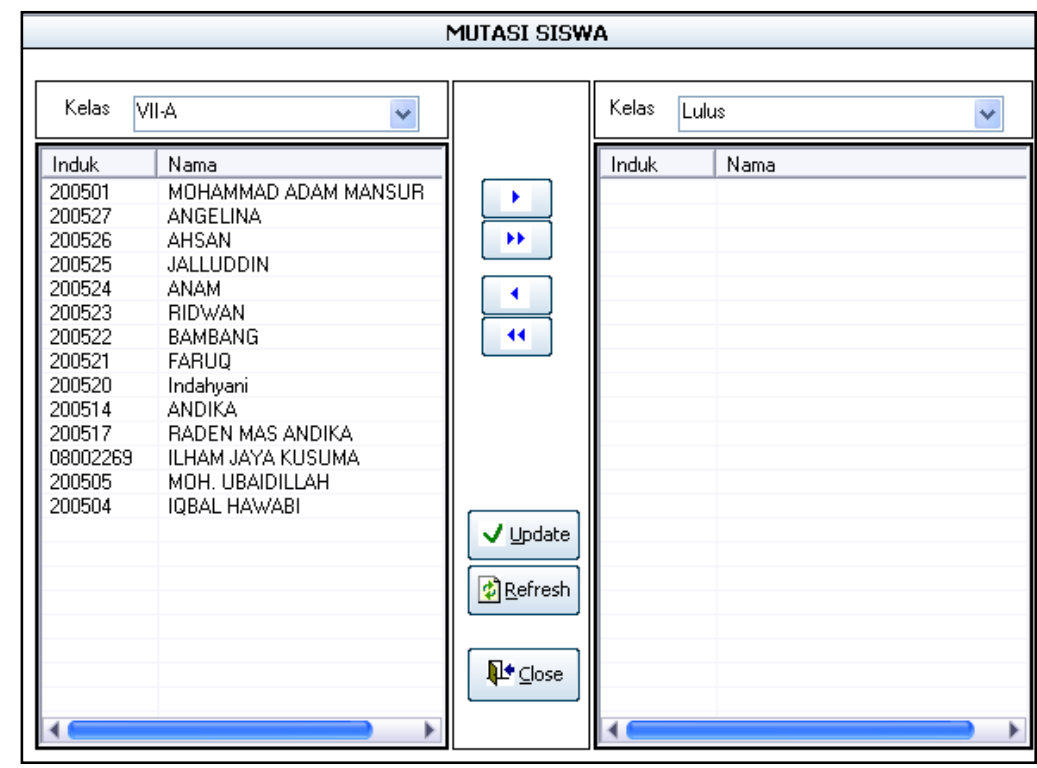

Gambar 4.6 Halaman Mutasi Siswa

Halaman untuk mengatur mutasi, kenaikan atau kelulusan siswa. Pilihan Kelas untuk menampilkan data siswa sesuai kelas. Tombol update untuk menyimpan perubahan, tombol refresh untuk merefresh data dan tombol close untuk keluar halaman ini. 
7) Halaman Kehadiran Otomatis

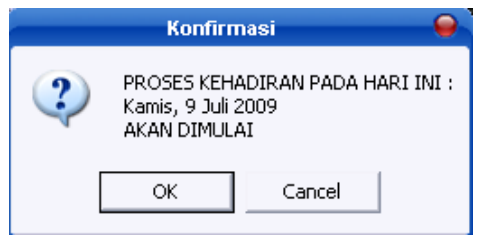

\begin{tabular}{|c|c|c|c|}
\hline \multicolumn{3}{|c|}{ PROSES KEHADIRAN OTOMATIS } & F* close \\
\hline \multicolumn{2}{|c|}{ Kamis, 9 Juli 2009} & & \\
\hline No. INDUK & AHMAD JUNAID & & \\
\hline No. Induk & Nama & Kelas & Kehadiran \\
\hline 200521 & FARUQ & VII-A & A \\
\hline 200517 & RADEN MAS ANDIKA & VIIIA & $16: 14: 45$ \\
\hline 08002269 & ILHAM JAYA KUSUMA & VII-A & A \\
\hline 200505 & MOH. UBAIDILLAH & VII-A & A \\
\hline 200504 & |QBAL HAWABI & VIII-A & A \\
\hline 200501 & MOHAMMAD ADAM MANSUR & VII-A & A \\
\hline 200520 & Indahyani & VIIIA & A \\
\hline 200522 & BAMBANG & VIIIA & A \\
\hline 200523 & RIDWAN & VIIIA & A \\
\hline 200524 & ANAM & VII-A & A \\
\hline 200525 & JALLUDDIN & VII-A & A \\
\hline 200526 & AHSAN & VII-A & A \\
\hline 200527 & ANGELINA & VIIIA & A \\
\hline 200514 & ANDIKA & VIIIA & A \\
\hline 200518 & AHMAD JUNAIDI & VIII-A & $16: 15: 02$ \\
\hline 200508 & MOH. ALAMSYAH & VIII-A & A \\
\hline 200511 & SITI MARFUAH & VIIII-A & A \\
\hline 200512 & MUJAYANAH & VIII-A & A \\
\hline 200509 & BAMBANG GENTOLET & VIII-A & A \\
\hline
\end{tabular}

Gambar 4.7 Halaman Kehadiran Otomatis

Halaman ini digunakan proses kehadiran siswa. Pada saat masuk halaman ini terdapat pesan bahwa proses kehadiran pada hari tersebut akan dimulai. Jika klik OK maka daftar hadir pada hari tersebut akan dibuat secara otomatis. Pengisian kehadiran ini dilakukan oleh siswa ketika datang ke sekolah dengan menunjukkan Kartu Tanda Siswa (KTS) di depan sensor barcode reader. Jika kartu tersebut dikenali secara otomatis akan tampil nama siswa tersebut di layar dan siswa tersebut dianggap telah hadir.

8) Halaman kehadiran manual (pengisian izin tidak hadir)

\begin{tabular}{|c|c|c|c|c|c|c|c|c|}
\hline \multicolumn{9}{|c|}{ PENGISIAN IZIN TIDAK HADIR } \\
\hline \multicolumn{2}{|c|}{ Kelas $\sqrt{ } \|-\mathrm{A}$} & $\checkmark$ & Tanggal & 09-07-2009 & $\cdot$ & A & 5 & I \\
\hline & No. Induk & \multicolumn{3}{|c|}{ Nama } & \multicolumn{3}{|c|}{ kehadiran } & \\
\hline \multirow[t]{13}{*}{$\nabla$} & 200504 & & \multicolumn{3}{|l|}{ A } & \\
\hline & 200505 & & \multicolumn{2}{|c|}{ MOH. UBAIDILLAH } & \multicolumn{3}{|l|}{ A } & \\
\hline & 08002269 & \multicolumn{3}{|c|}{ ILHAM JAYA KUSUMA } & \multicolumn{3}{|l|}{ A } & \\
\hline & 200514 & \multicolumn{3}{|l|}{ ANDIKA } & \multicolumn{3}{|l|}{ A } & \\
\hline & 200520 & \multicolumn{3}{|l|}{ Indahyani } & \multicolumn{3}{|l|}{ A } & \\
\hline & 200521 & \multicolumn{3}{|l|}{ FARUQ } & \multicolumn{3}{|l|}{ A } & \\
\hline & 200522 & \multicolumn{3}{|l|}{ BAMBANG } & \multicolumn{3}{|l|}{ A } & \\
\hline & 200523 & \multicolumn{3}{|l|}{ RIDW/AN } & \multicolumn{3}{|l|}{ A } & \\
\hline & 200524 & \multicolumn{3}{|l|}{ ANAMM } & \multicolumn{3}{|l|}{ A } & \\
\hline & 200525 & \multicolumn{3}{|l|}{ JAALLUDDIN } & A & \multirow{2}{*}{\multicolumn{2}{|c|}{$\mathrm{A}$}} & \\
\hline & 200526 & \multicolumn{3}{|l|}{ A.HSAN } & \multicolumn{2}{|l|}{ A } & & \\
\hline & 200527 & \multicolumn{3}{|l|}{ ANGELINA } & \multicolumn{3}{|l|}{ A } & \\
\hline & 200501 & \multicolumn{3}{|c|}{ MOHAMMAD ADAM MANSUR } & \multicolumn{3}{|l|}{ A } & \\
\hline
\end{tabular}

Gambar 4.8 Halaman Kehadiran Manual

Halaman ini digunakan untuk mengisi daftar hadir bagi siswa yang tidak masuk tetapi mengirimkan surat keterangan tidak masuk. Pilihan kelas digunakan untuk menampilkan data sesuai kelas, pilihan tanggal digunakan untuk menampilkan daftar hadir tanggal tersebut. Tombol A, S, I digunakan untuk mengisi kehadiran. (A = Alpha, S = Sakit, I = Izin). 
9) Halaman SMS Manajer (Setting)

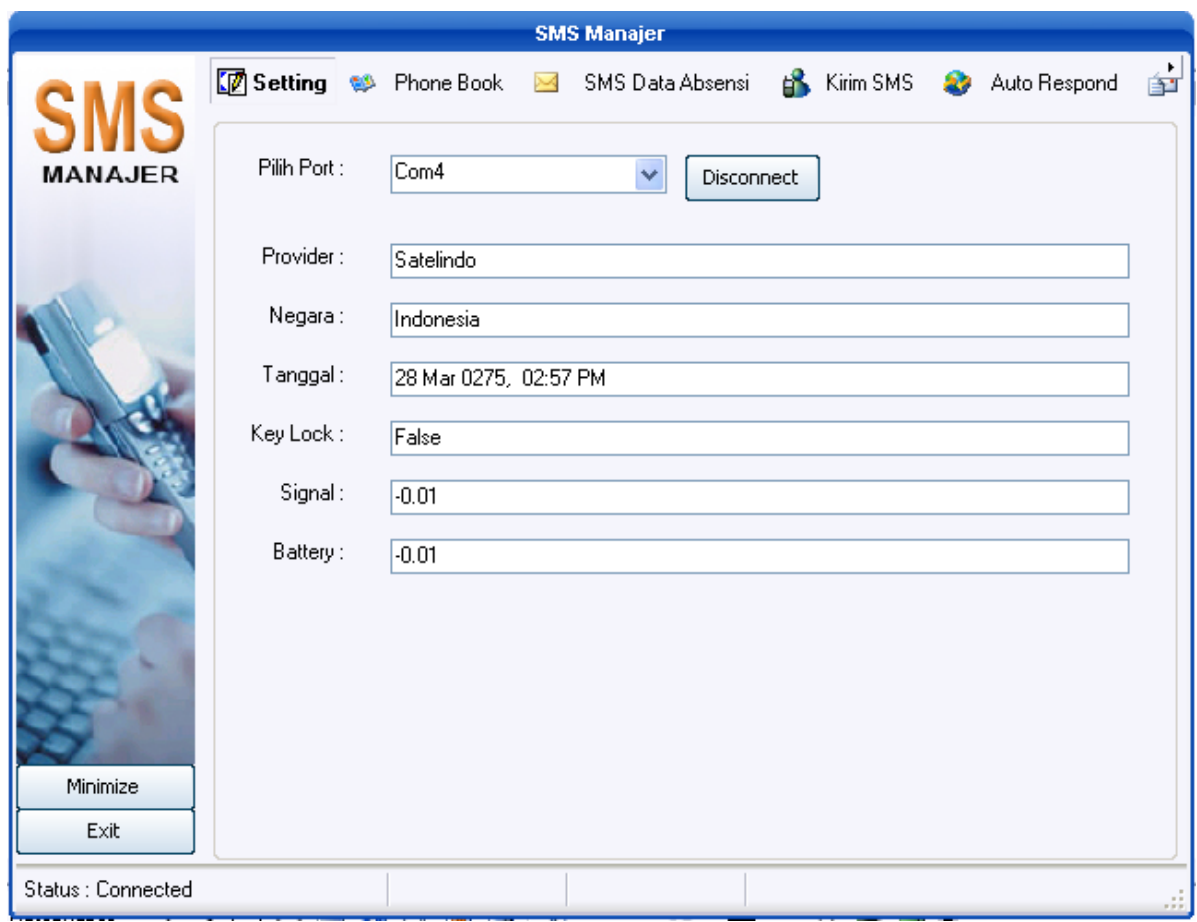

Gambar 4.9 Halaman SMS Manajer (Setting)

Halaman ini digunakan untuk mengatur koneksi antara komputer dengan handphone. Pilihan port digunakan untuk memilih jalur port dari Handphone yang dipakai, tombol connect / disconnect digunakan untuk memberi perintah terhubung atau terputusnya koneksi antara Handphoe dan komputer.

10) Halaman SMS Manajer (Phone Book)

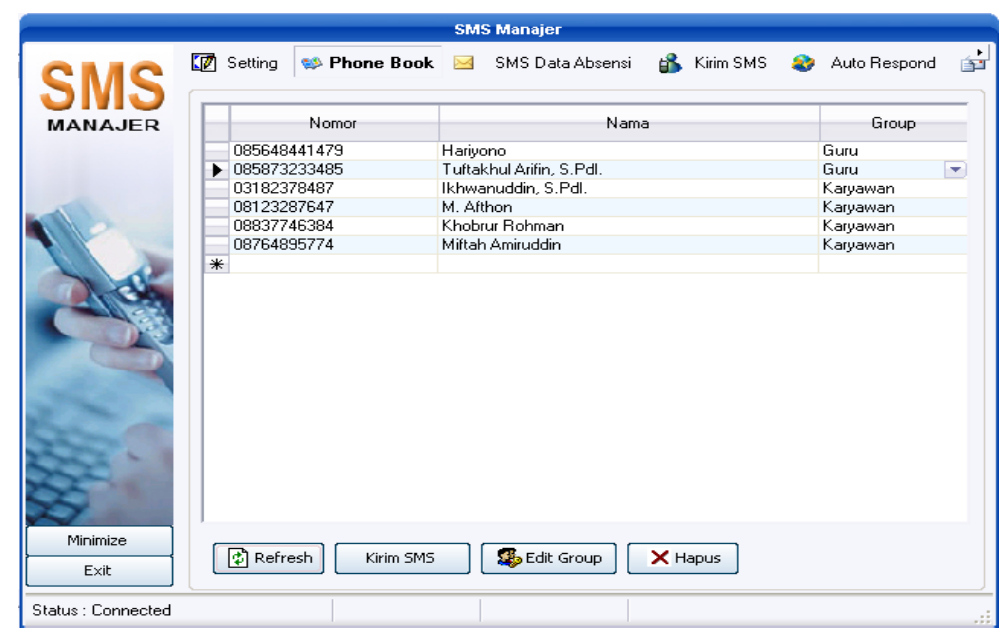

Gambar 4.10 Halaman SMS Manajer (Phonebook)

Halaman ini digunakan untuk memasukkan nomor handphone yang mungkin berhubungan dengan penanganan absensi siswa seperti guru ataupun karyawan. Setiap nomor handphone dikelompok dalam sebuah group. Hal ini berguna jika akan mengirim SMS ke beberapa nomor dengan cara memilih nama group saja. 
11) Halaman SMS Manajer (SMS Data Absensi)

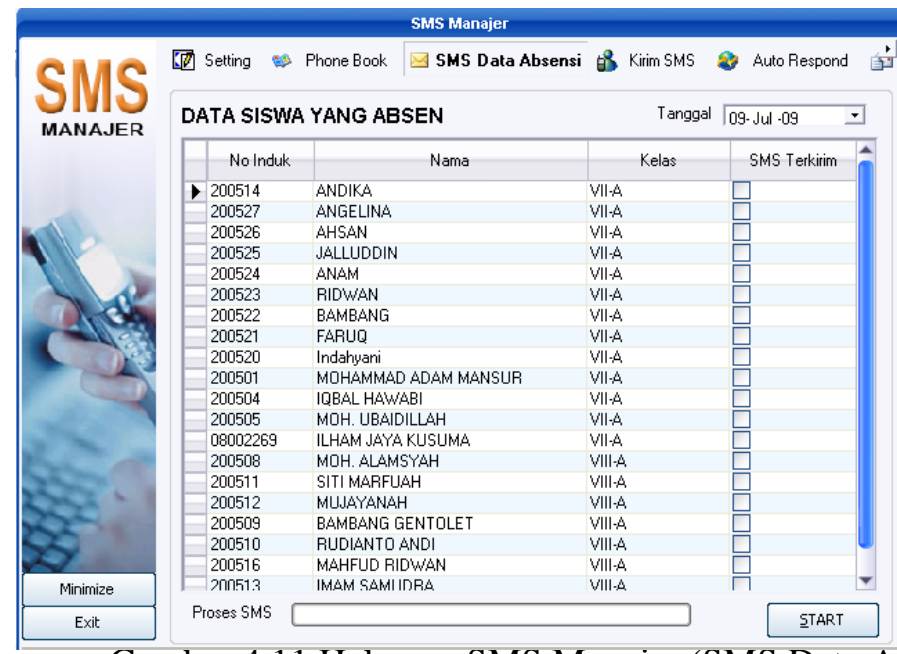

Gambar 4.11 Halaman SMS Manajer (SMS Data Absensi)

Halaman ini digunakan untuk mengirimkan sms kepada orangtua / pengurus asrama bagi siswa yang tidak masuk tanpa keterangan (absen) pada tanggal sesuai dengan pilihan tanggal. Tombol start digunakan untuk memulai pengiriman sms. Jika sms telah terkirim maka pada kolom sms terkirim terdapat ceklist.

12) Halaman SMS Manajer (Kirim SMS)

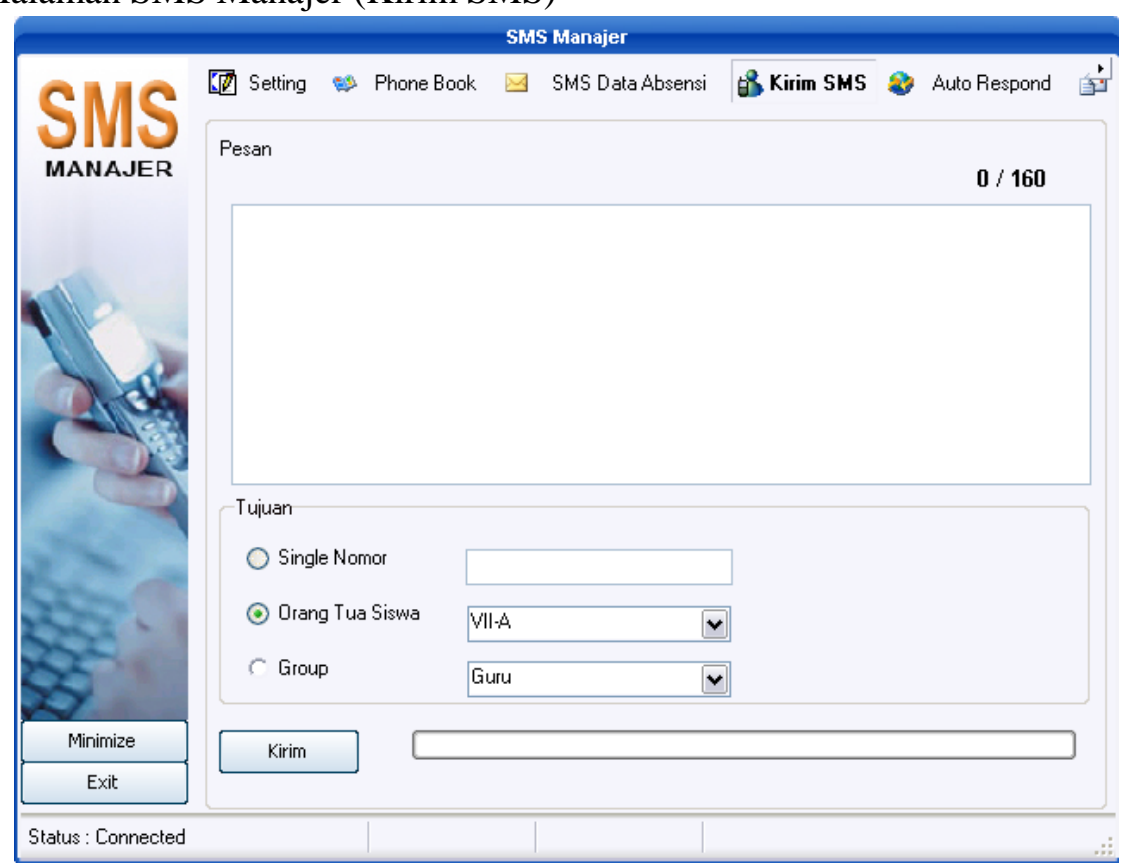

Gambar 4.12 Halaman SMS Manajer (Kirim SMS)

Halaman ini digunakan untuk mengirim sms ke satu nomor atau beberapa nomor. Baik kepada wali siswa atau kepada group dari phonebook. Pengiriman sms ini berfungsi jika ada pemberitahuan atau undangan kepada wali siswa / guru / karyawan / dan lain-lain. Tombol kirim digunakan untuk memulai pengiriman sms. 
13) Halaman SMS Manajer (Auto Respon)

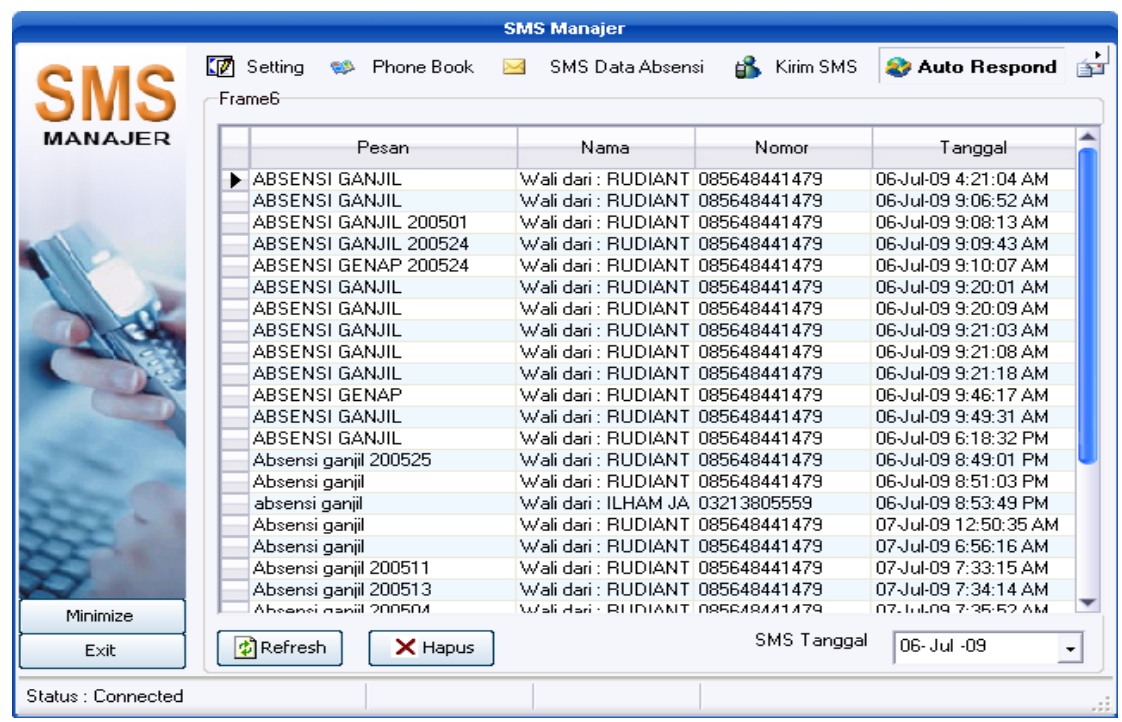

Gambar 4.13 Halaman SMS Manajer (Auto Respon)

Halaman ini berfungsi untuk menampilkan data SMS request dari pihak orang tua atau nomor handphone yang sudah teregister. SMS request akan dibalas secara otomatis apabila format SMS yang masuk benar, yaitu [ABSENSI] [SPACE] [GANJIL/GENAP] atau [ABSENSI] [SPACE] [GANJIL/GENAP] [INDUK SISWA] dan nomor tersebut teregistrasi. Jawaban yang dikirim kepada nomor yang request berupa rekap ketidakhadiran seorang siswa dalam satu semester.

14) Halaman SMS Manajer (SMS Inbox)

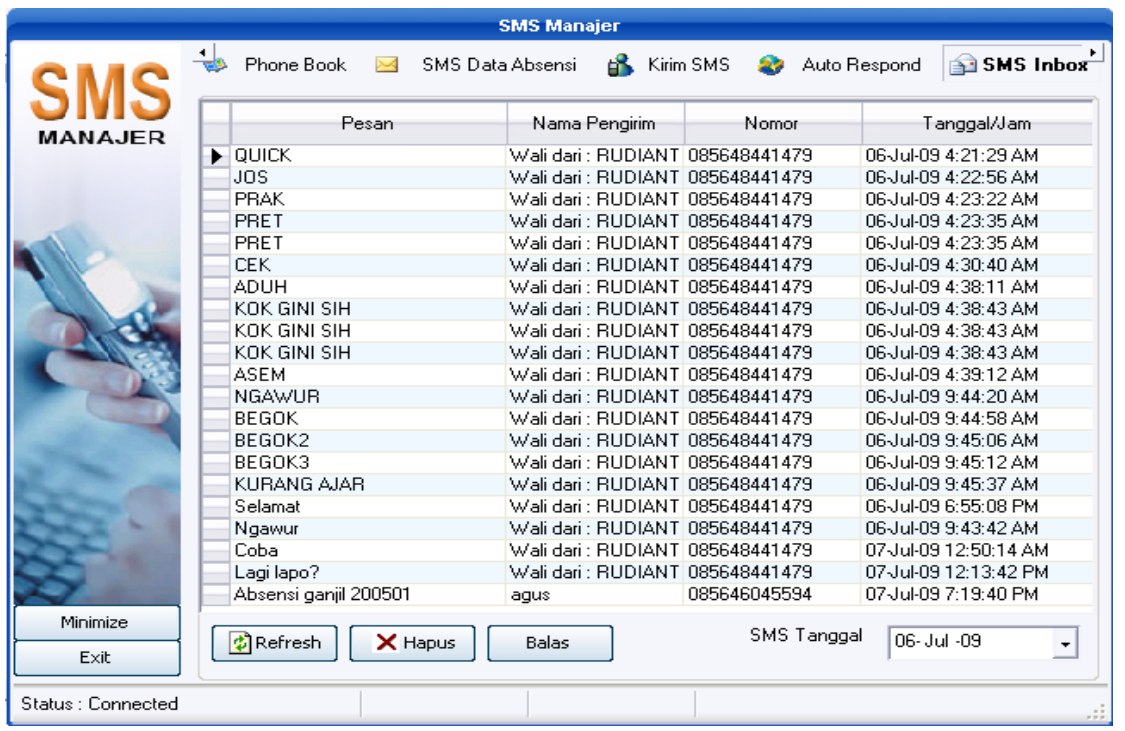

Gambar 4.14 Halaman SMS Manajer (SMS Inbox)

Halaman SMS inbox digunakan untuk menampilkan data SMS yang masuk selain SMS request. Pilihan tanggal digunakan untuk menampilkan sms sesuai dengan tanggal yang dipilih saja. Tombol refresh untuk menampilkan semua SMS masuk, tombol hapus untuk menghapus SMS dan tombol balas untuk memberi balasan SMS yang masuk. 
15) Halaman SMS Manajer (SMS Outbox)

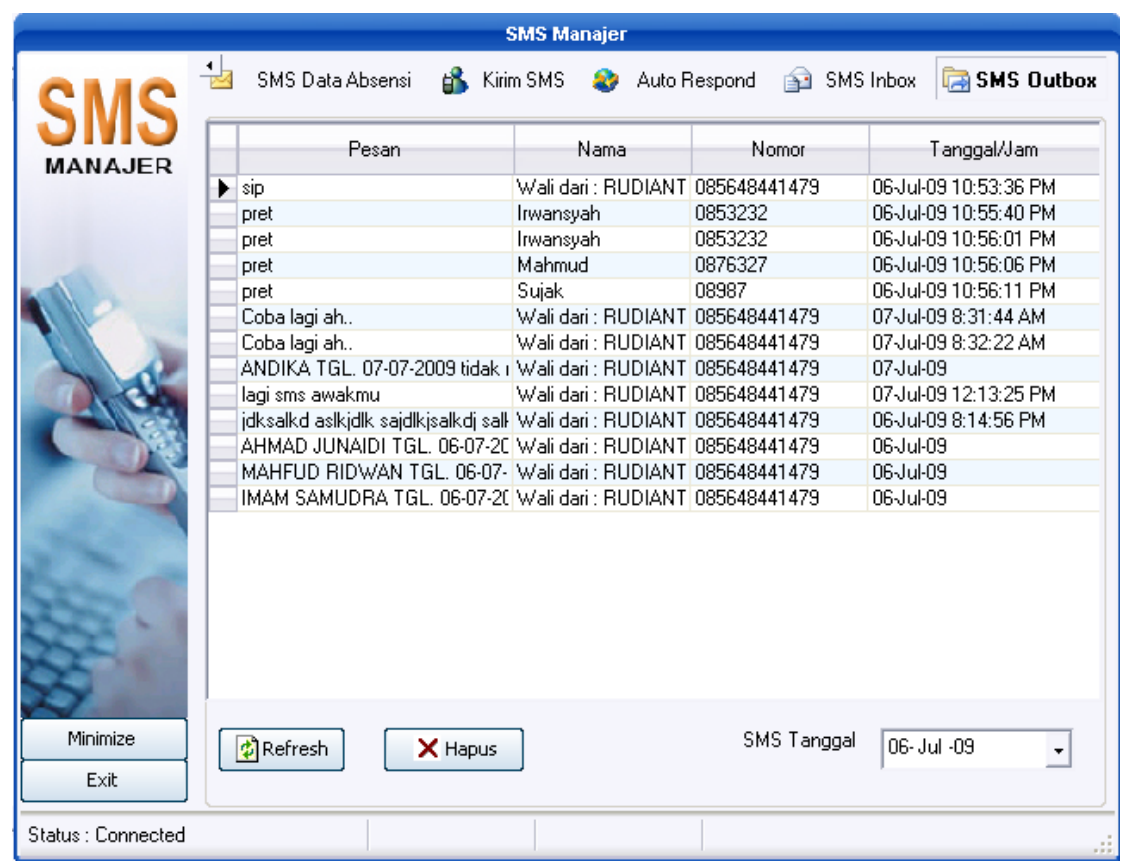

Gambar 4.15 Halaman SMS Manajer (SMS Outbox)

Halaman SMS outbox digunakan untuk menampilkan data SMS keluar. Pilihan tanggal untuk menampilkan SMS keluar sesuai dengan tanggal yang dipilih. Tombol refresh untuk menampilkan semua SMS keluar dan tombol hapus untuk menghapus sms keluar.

16) Halaman Report

a. Report rekap kehadiran perbulan

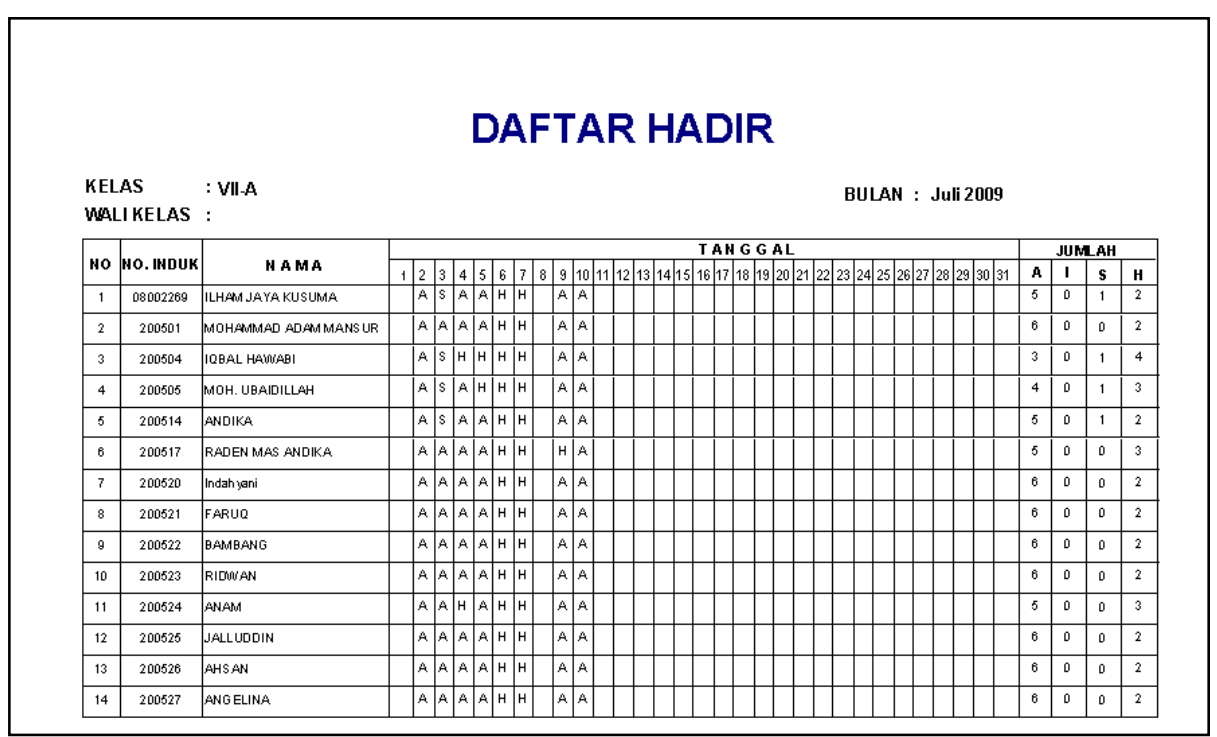

Gambar 4.16 Report rekap kehadiran perbulan 
b. Report rekap kehadiran persemester

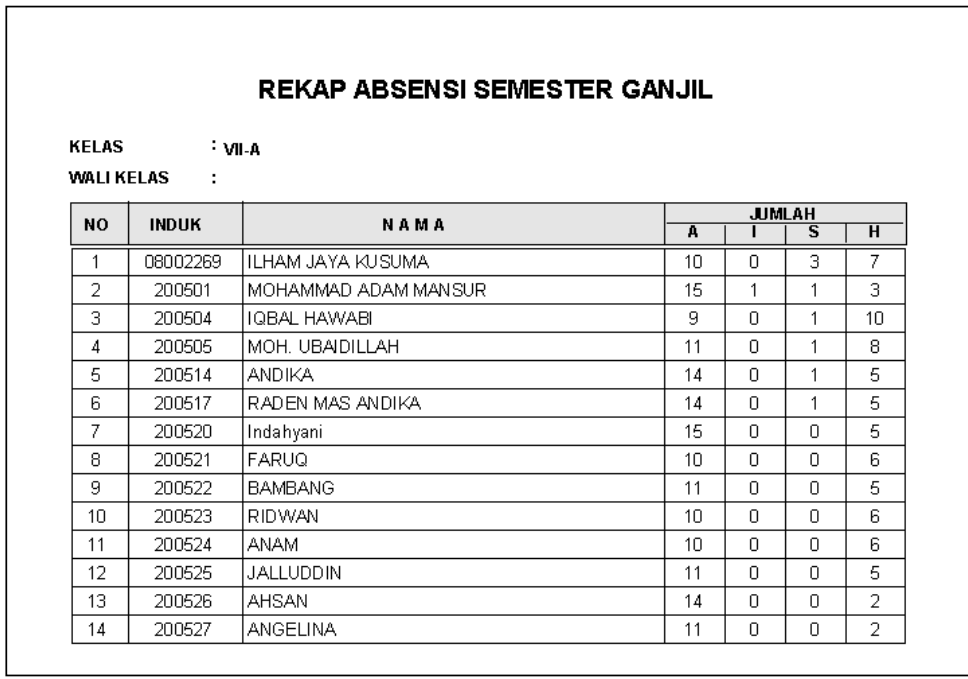

Gambar 4.17 Report rekap kehadiran persemester

c. Report Kartu Tanda Siswa (KTS)

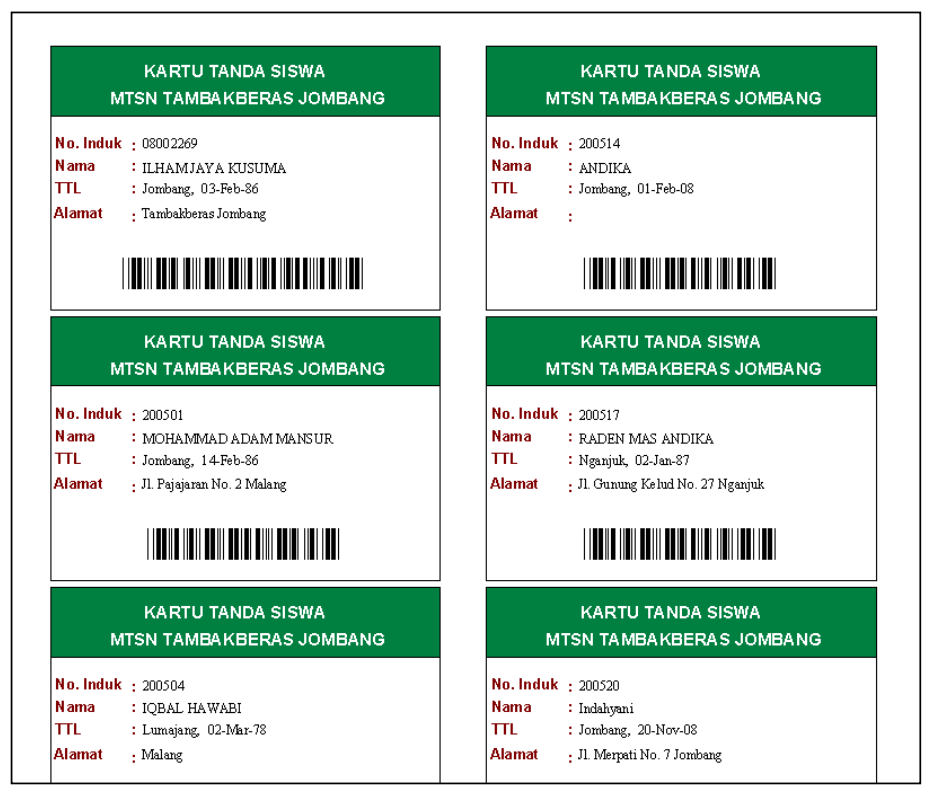

Gambar 4.18 Report rekap Kartu Tanda Siswa (KTS)

\subsection{Evaluasi}

\subsubsection{Evaluasi Hardware}

Evaluasi yang dilakukan untuk hardware dengan spesifikasi yang ditentukan bahwa program ini dapat berjalan dengan baik dan tidak dapat crush yang disebabkan oleh kurangnya jumlah spesifikasi yang dianjurkan.

\subsubsection{Evaluasi Software}

Evaluasi yang dilakukan untuk software dengan spesifikasi yang ditentukan adalah bahwa program ini dapat berjalan dengan baik dengan spesifikasi yang diberikan seperti:

1. Windows XP 
Sistem operasi ini dipilih untuk pengoperasian program yang lain karena program lain itu semua diinstall berbasiskan windows sehingga untuk menjalankan program tersebut harus ada windows. Jenis windows yang dipakai adalah windows XP karena windows XP mempunyai performa yang tinggi jika dibandingkan dengan windows yang lain.

2. Visual Basic 6.0

Program ini berjalan dengan baik dengan spesifikasi komputer yang diberikan. Program ini digunakan untuk merancang aplikasi ini karena struktur kodenya mudah dipahami dan sangat kompatibel dengan kontrol luar (active controlx) sehingga pembuatan suatu aplikasi bisa lebih mudah dan luas.

3. Adobe Photoshop

Program ini juga dapat dijalankan baik dengan spesifikasi yang diberikan. Program digunakan untuk membuat desain tampilan form. Penggunaan program ini juga sangat mudah dengan banyaknya help dan user interface yang memudahkan kita untuk mendesain tampilan form agar terlihat menarik.

\section{KESIMPULAN DAN SARAN}

\subsection{Kesimpulan}

Berdasarkan hasil uji coba yang dilakukan terhadap program ini dengan mengevaluasi dari segi hardware dan software serta penggunaannya sehingga didapatkan kesimpulan bahwasanya Sistem Informasi Pemantauan Absensi Siswa Berbasis SMS dapat membantu pemantauan absensi/kehadiran siswa di sekolah oleh orang tua melalui SMS tanpa dibatasi waktu dan tempat secara up to date dengan biaya yang murah. Dengan komunikasi yang efektif, pengawasan terhadap anak dapat berjalan sesuai dengan harapan.

\subsection{Saran}

Diharapkan bagi pihak sekolah untuk menyediakan perangkat komputer be seralatan pendukung aplikasi tersebut, sehingga proses pemantauan absensi siswa menja .ncar dan kedisiplinan siswa dapat ditingkatkan.

Sedangkan bagi orang tua, gunakan fasilitas yang disediakan oleh pihak sekolah dengan sebaik-baiknya.

\section{DAFTAR PUSTAKA}

Ir.Haryanto, Kristanto,1998, Konsep dan Perancangan Data Base, Andi Offset, Yogyakarta

Jogianto, HM, 1993, Analisa dan Desain Sistem Informasi Pendekatan Terstruktur Teori dan Aplikas Praktek Bisnis, Andi Offset, Yogyakarta.

Kasmoni, 2001, Microsft Visual Foxpro 8.0, Maxikom, Palembang.

Ms, Nugroho Eko, 1997, Pengolahan Instalasi komputer, Andi Offset, Yogyakarta.

Wahana Komputer, Pemrograman Visual Basic Tingkat Lanjut, Andi Offset, Yogyakarta.

Winardi, SE, DR, 1993 , Sejarah Ilmu Perkembangan Ekonomi, Tarsito, Bandung. 